\title{
Construction and Constructivism: Learning Contract Management and Administration via Simulated Transactions
}

\author{
Andrew Agapiou, Lecturer \\ Department of Architecture, University of Strathclyde
}

Paul Maharg

Emma Nicol, Research Assistant

School of Law, University of Strathclyde

\begin{abstract}
The higher education sector is being confronted with a confluence of radical changes including rapidly evolving bodies of interdependent knowledge and skills, growing numbers of students, decreasing funding, and demand for flexible and individually tailored pedagogical frameworks. Some of these changes are antithetical with other changes whereas some call for radical rethinking of traditional teaching and learning strategies. To address the challenges of wider educational change and our local conditions, Strathclyde University has developed an approach to professional simulations called SIMPLE (SIMulated Professional Learning Environment). One aspect of the project focuses on developing an interactive digital learning environment to enable postgraduate Architecture students to learn some aspects of the Management, Practice and Law syllabus. This syllabus is arguably rather abstract in its content, and our hypothesis was that the development of a simulation environment could provide a more effective and engaging method for learning professional knowledge and skills. This paper describes the design, pedagogical structure, implementation and evaluation of the SIMPLE simulation within this module.
\end{abstract}

Keywords: Architecture, Contract Administration, Simulation, Transactional Learning and Teaching 
A. Agapiou, P. Maharg \& E. Nicol: Construction and Constructivism: Learning Contract Management and Administration via Simulated Transactions

\section{Introduction}

Built Environment education entails the acquisition of complex technical knowledge by students. Currently, the conventional lecture format is the dominant educational method used, with the main principle being that of information transfer. As the required knowledge base increases, so the ability of the students to effectively absorb and use information is reduced. There is, therefore, an identifiable need to establish alternative modes of learning for students. Multi-media systems may present themselves as ideal mechanisms for this. However, potential problems exist in the seamless integration of such technology with established teaching and learning programmes. Flexibility and ready access by students of different aptitudes and skills are commonly-cited gains in the use of multi-media. However if the use of multi-media on a large scale is to be effective, its integration into traditional HE programmes must be addressed. The issue is complex and is made more difficult by the exigencies of timetabling. At the University of Strathclyde, for example, the subjects of project and contract management are studied by students in Architecture and Urban Design. Traditionally they have been taught in large groups in a lecture theatre, with each of the disparate groups of students having individual learning objectives.

Like many Architecture Schools worldwide, the University of Strathclyde is radically redesigning its curriculum and its approach to the design of Architecture programmes.

At the core of this restructuring is the need for:

- students to appreciate the inter-dependencies between design documentation, project management, contract administration, and building and construction economics

- $\quad$ staff to develop a decision-making and problem-solving culture among students.

Numerous innovative, interactive tools have been used for some time, to enable students develop project and contract management skills. The use of simulated environments is nothing new (see, O'Leary, 1997; Agapiou, 2006; Deshpande and Huang, 2009). Most of the simulations mentioned above however, are either paperbased or have been developed with limited use of advanced computer technology. Indeed, while the Strathclyde team had previously developed and deployed a firstgeneration simulation system to teach contract management to Architecture students, the technology utilised was rather archaic relying on an instant messaging facility with limited capacity for communication, data storage and retrieval (Agapiou, 2006). With the advent of Learning Management Systems the use of multimedia and the expansion of communication platforms, there exists much more opportunity to enable students to learn professional practice, the contractual process and other specific needs of Architecture students. Active participation of practitioners was also not a welldeveloped feature of the first-generation system. For this reason we turned to the SIMPLE project and in particular to transactional learning as a mode of learning and assessment. 
A. Agapiou, P. Maharg \& E. Nicol: Construction and Constructivism: Learning Contract Management and Administration via Simulated Transactions

Within the SIMPLE environment real and idealised building projects are used to illustrate and reinforce the relatedness and independency of Architecture subjects. The long-term aim of the project is to develop a holistic set of digital teaching and learning modules for some aspects of the post-graduate programme in Architecture in the Department, providing a unique opportunity for students to follow the process of the construction of a building. The module creates a dynamic link between a range of design decisions and cost/time factors associated with the scheduling of a major building project. The system itself is an interactive application which can integrate software, plans, diagrams and documentation. This paper describes the philosophy and pedagogy behind its development and the way in which the system is integrated into the assessment of the Architecture Practice, Management and Law curriculum.

\section{Transactional Learning}

The SIMPLE project (SIMulated Professional Learning Environment) is a two-year project funded jointly by JISC (Joint Information Services Committee) and the Higher Education Academy through the UKCLE (UK Centre for Legal Education). It aims to:

- Enhance student learning across professional curricula in FE and HE

- Create a simulation environment that can be used by both students in FE and $\mathrm{HE}$, and by professional training organisations, thus bridging forms of learning between academic programmes and continuous professional development

- Develop a tool suite that will enable staff to engage with students in simulations that site learning firmly within professional contexts

- Contribute to research on the use of e-simulations and professional learning, and large-scale implementation within an institution

- Raise awareness amongst staff of the usefulness of simulation learning techniques for undergraduate and postgraduate curriculum design and teaching

- Begin a collection of case studies across the professions that can form the core of an ongoing community of practice.

The project is interdisciplinary. Originally arising out of the practice of the Glasgow Graduate School of Law (GGSL) at Strathclyde University, it now includes law schools at Glamorgan, Warwick and Stirling; and the schools of Architecture, Management Science and Social Work at Strathclyde. This is of the essence: one of the aims of the project was to prove that simulation of a professional environment could be successful not merely in law but in any client-focused profession. At the Glasgow Graduate School of Law during the period 2000-2006 at least six iterations of an environment were designed. These consisted of a fictional town on the web, Ardcalloch, the cultural and topographical lineaments of which were modelled on a typical Scottish west coast provincial town. Within the town, represented online by a history (stretching back 


\section{A. Agapiou, P. Maharg \& E. Nicol: Construction and Constructivism: Learning Contract}

Management and Administration via Simulated Transactions

through seven periods to the eighth century CE) were a map and a directory of businesses, institutions and citizens.

Within the town were sited the virtual law firms - in 2008, for instance, 272 students were divided into 68 firms, four students per firm, and played the role there of trainees within the firm. They completed legal transactions - they bought and sold property over the web, for instance, or represented clients in an adversarial personal injury prelitigation negotiation.

A body of educational theory, called transactional learning, has been developed around the use of the simulation environment, described in detail elsewhere (Maharg, 2006; 2007; Barton \& Maharg, 2006; Barton et al., 2007). Our approach in the SIMPLE project could be summarised in the following seven general points:

1. Transactional learning is active learning. Transactional learning should be active learning, not passive. In that sense, we want students to be involved in activities within legal actions, rather than standing back from the actions and merely discussing them. There is, of course, a place for learning about legal actions. Indeed, transactional learning is rarely possible unless students first have a conceptual understanding of what the process actually entails.

However, transactional learning goes beyond learning about practice to learning from practice. We would claim that there are some forms of professional learning that can only take place if students go through the process of active learning.

2. Transactional learning is based on doing transactions. As befits the type of learning that students do on both undergraduate and postgraduate professional programmes, we aim to give them experience of transactions. They thus learn considerably more about the practical realities of professional actions within the work, and which elements of academic knowledge are directly applicable to professional practice.

3. Transactional learning involves reflection on learning. Transactional learning involves thinking about transactions - indeed (to go back to the root of the word) thinking across transactions. For students it includes the ability to rise above detail, and 'helicopter' above a transaction; or the development of the ability to disengage themselves from potentially damaging views of the group process within the firm, and re-construct that view. It includes documenting firm transactions.

4. Transactional learning is based on collaborative learning. Transaction is defined also as collaboration, another form of 'acting across'. Students are valuable resources for each other, particularly if they have opportunities to engage in both cumulative talk (the accumulation and integration of ideas) and exploratory talk (constructive sharing of ideas around a task) (see for instance, van Boxtel 
A. Agapiou, P. Maharg \& E. Nicol: Construction and Constructivism: Learning Contract Management and Administration via Simulated Transactions

et al., 2000). In the GGSL, for instance, around 70 'virtual firms' of four students were created, in which students carried out transactions using the virtual community. Such collaborative learning breaks down the isolation and alienation of what might be regarded as individual or cellular learning. There is of course a place for individual learning, silent study, literature review and so on, and we emphasise this as a preparation for collaborative work. But students can help each other enormously to understand legal concepts and procedures by discussing issues, reviewing actions in a group, giving peer feedback on work undertaken in the group, and so on.

5. And perhaps what is even more important is that in the process of doing so, they have the opportunity to begin to trust each other to carry out work that is important (there is high-stakes assessment value to the projects). In other words, students begin to learn how to leverage knowledge amongst themselves, and to trust each other's developing professionality (learning about know-who, know-why, as well as know-what within the firm). Often, we have found, if there are virtual firms that are not producing acceptable standards of work or keeping to deadlines, it is because they are not working together effectively; and this often arises from a lack of trust (Barton \& Westwood, 2006).

6. Transactional learning requires holistic or process learning. In seminars and lectures and in their reading of texts, students engage with ideas, and form understandings of disciplinary concepts, the identity and purpose of documents, actions and the like. However such learning is part-to-whole; we also need to give students opportunities for whole-to-part learning, and for learning about legal process. The transactional projects provide the environment for this form of learning. In this sense, the learning arena can truly be called a transactional learning environment.

Through observation of our students working in this environment we have also added the following characteristics to the original list of five to further define what we mean by transactional learning:

7. Transactional learning is based on immersion in professional role-play. An important aspect we have observed is that students engaged in transactional learning are not simply involved in progressing a simulated transaction within what we might consider a relatively safe environment, but they are in fact taking part in a much more sophisticated process that involves them taking on the persona of a professional within the virtual spaces of Ardcalloch and their student 'firm'. Interaction with other student firms as well as fictional and simulated clients (Barton et al., 2006) provide opportunities for students to engage in professional role play at a much deeper level than is otherwise possible in a traditional classroom setting. At this level, understanding and application of the relevant principles, codes of conduct and ethical issues 
A. Agapiou, P. Maharg \& E. Nicol: Construction and Constructivism: Learning Contract Management and Administration via Simulated Transactions

become explicit, and personal responsibility is developed in a way that is not possible in any other learning environment other than placement or clinic work.

8. Transactional learning relies on task authenticity. It has been argued, in relation to on-line learning environments, that authentic settings have the capability to motivate and encourage learner participation by facilitating students 'willing suspension of disbelief'. This allows students to become immersed in the setting, providing motivation and encouraging perseverance in tasks. Without this task authenticity, full engagement in professional role-play is compromised and the learning gained from that personal experience and interaction reduced. Task authenticity, like authenticity in the Early Music debates, cannot be reduced to any single component, but is a function of the interaction of the whole. The analysis by Barab et al. (2000) of how authenticity arises from the 'dynamic interactions' of elements within an environment or field (quoted above) expresses this well.

\section{SIMPLE User Interface, structure and development platform}

SIMPLE consists of a set of tools and a platform which runs the simulation. The tools enable staff to create a simulation by defining characters, roles, communications to be sent and/or received, time limits and other variables. Student details are entered into the platform, and the platform can then be used to run the simulation.

The user interface has been designed as a generic client interface. It gives users a communication platform as well as a document store. It also gives staff the opportunity to embed within the environment a wide range of simulation resources. Graphics, photographs, video, document formats, document style banks, web resources, links to internet resources - all these can be supported.

The simulations themselves can be designed as highly structured, with specific document flows and fixed procedures (what we call bounded transactions) or they can be highly open and porous, where there are no fixed procedures, and where characters can be added to the simulation while it is in process, to give a sense of the authenticity of the simulation and random qualities of reality.

\section{Description of Educational Context}

The simulation was deployed within the taught element of the ARB/RIBA Part II Management, Practice and Law syllabus. The Design Management and Practice (DMP) class aims to develop knowledge and skills in order to equip Postgraduate students with an understanding of the organisational and legal issues associated with the practice of architecture, and to establish competence for those wishing to register as Architecture professionals, within the framework of the class learning objectives (see below) and the Architects Registration Board (ARB) Part II Management Practice and Law criteria. 
A. Agapiou, P. Maharg \& E. Nicol: Construction and Constructivism: Learning Contract Management and Administration via Simulated Transactions

\section{Design Management and Practice Module specific learning outcomes}

Knowledge and understanding on completion:

- How cost control mechanisms operate within the development of an architectural project

- The basic principles of business management and factors related to running a design practice and how architects organise, administer and manage an architectural project, recognising current and emerging trends in the construction industry such as partnering, integrated project process, value engineering and risk management

- The inter-relationships of individuals and organisations involved in the procurement and delivery of architectural projects, and how these are defined and effected through a variety of contractual and organisational structures

- The fundamental legal, professional and statutory requirements as they are relevant to building design and practice, with particular reference to matters relating to health and safety and universal design for access

- The professional duties and responsibilities of architects, as defined and described in the Codes and Standards relating to their professional practice

\section{Professional Practical skills:}

- Identify and manage individual learning needs so as to prepare for and maintain professional standards commensurate with qualification

The class is a compulsory element of the Postgraduate Diploma in Advanced Architectural Design. One of the main specific learning outcomes of the class is to provide an introduction to the process, systems and documentation which are required for administration of a building project encompassing the legal aspects of the construction process as well as the concepts of responsibility and liability on the part of the Architectural practitioner.

In addition to providing a useful environment for the acquisition and exploration of these bodies of knowledge, the simulated environment also provided students with an interactive learning setting for the development of team working and decision-making skills.

In essence, the project was quite straightforward, deceptively so. The students were divided into 10 teams, comprising four participants. The size of the group was not predetermined but it was felt that four participants per team were ample given the nature of the SIMPLE system.

The students' objective was to administer the construction process in response to 16 tasks or transactions as set out by a chronology of likely on-site scenarios relating to the deployment of the JCT/SBCC 1998 standard building contract with quantities. To this end they entered into correspondence with the client, contractor and other consultants as required.

The transactions were grouped around three themes associated with the administration of a building contract including: undertaking works activities; scheduling of the works; 
A. Agapiou, P. Maharg \& E. Nicol: Construction and Constructivism: Learning Contract Management and Administration via Simulated Transactions

as well as financial matters. Additional tasks within the simulation related the responsibilities to any of the other parties involved in the building process, including issues relating to parties' contractual responsibilities and obligations.

The exercise was intended to simulate events covering the construction of a new office development over a contract period of 18 months located within Arcalloch. The students were told that the project had reached stage $\mathrm{J}$ of the RIBA Plan of Work. The exercise begins following the recommendation by the Architect to appoint the Contractor. Each group of students was asked to cope with the same sequence of events but the development of any given scenario could well differ between groups depending on the respective actions taken - it was assumed also that the rate of groups' progress would vary. Academic staff acted as Employer, Contractor, Quantity Surveyors, Structural Engineer, Clerk of Works etc and each scenario was presented to the Architect in a numbered sequence as illustrated in Table 1. Academic staff, acting in Partner role, were also required to monitor the development of the exercise, offer advice or help, to avoid, for example, unwarranted determination of the contract or premature arbitration. The groups were further advised that actions decided upon should be in line with "good practice" and should conform to the JCT 1998 Conditions of Contract, terms of engagement under SCA/2000 and the ARB Code of Professional Conduct.

Table 1 Description of Building Contract Scenarios (developed by ASSA)

\begin{tabular}{|l|l|l|l|}
\hline $\begin{array}{l}\text { Task } \\
\text { No. }\end{array}$ & \multicolumn{1}{|c|}{ Description } & $\begin{array}{l}\text { Task } \\
\text { No. }\end{array}$ & \multicolumn{1}{|c|}{ Description } \\
\hline 1 & $\begin{array}{l}\text { The starting point of the simulation is a } \\
\text { memo sent by the Senior Partner to the } \\
\text { project Architect [the students]. The } \\
\text { memo instructs the Architect to put in } \\
\text { place the necessary contract } \\
\text { documentation [acceptance] and } \\
\text { requests taking the necessary steps to } \\
\text { ensure an early commencement date } \\
\text { following the agreement to accept the } \\
\text { tender submitted for the erection of the } \\
\text { Office Block. }\end{array}$ & 9 & $\begin{array}{l}\text { The Contractor advises that they are } \\
\text { claiming an extension of time of six } \\
\text { weeks because of the recent strike of } \\
\text { bricklayers which lasted that time. } \\
\text { They advise that scaffolding charges } \\
\text { for that six week period were non- } \\
\text { productive and therefore require to be } \\
\text { paid for these. They request the } \\
\text { necessary certificates as soon as } \\
\text { possible. The Architect is required to } \\
\text { respond to the contractor with } \\
\text { reference to the appropriate clause in } \\
\text { the contract. }\end{array}$ \\
\hline 2 & $\begin{array}{l}\text { Now that the contract has been let, the } \\
\text { Architect is asked by one of the } \\
\text { Practice Partners to compile an } \\
\text { Agenda for a Pre-contract Meeting } \\
\text { [between Consultants and Main } \\
\text { Contractor] to be held. }\end{array}$ & 10 & $\begin{array}{l}\text { The contractor notifies that they have } \\
\text { now let the sub-contract of the plumber } \\
\text { work. They advise that only one firm } \\
\text { were able to undertake the work in the } \\
\text { time required and this will result in an } \\
\text { increase in the Contract sum. The } \\
\text { contractor requests the issue of the } \\
\text { appropriate Architect's instruction. The } \\
\text { Architect is required to respond to the } \\
\text { contractor and prepare the appropriate } \\
\text { documentation accordingly. }\end{array}$ \\
\hline
\end{tabular}


A. Agapiou, P. Maharg \& E. Nicol: Construction and Constructivism: Learning Contract Management and Administration via Simulated Transactions

\begin{tabular}{|c|c|c|c|}
\hline 3 & $\begin{array}{l}\text { The Architect is asked by the contractor } \\
\text { to arrange to have the building set out } \\
\text { on site to enable us to proceed with the } \\
\text { work without delay. The Architect is } \\
\text { required to respond to the contractor } \\
\text { with reference to the appropriate clause } \\
\text { in the contract. }\end{array}$ & 11 & $\begin{array}{l}\text { During the course of a Monthly } \\
\text { Progress Meeting, a car, which is } \\
\text { parked in the space allowed adjacent to } \\
\text { the Site Office, is badly damaged by a } \\
\text { precast concrete cladding unit falling off } \\
\text { a truck. The Architect is required to } \\
\text { respond to the contractor with } \\
\text { reference to the appropriate clause in } \\
\text { the contract. }\end{array}$ \\
\hline 4 & $\begin{array}{l}\text { The contractor has sent a copy of their } \\
\text { programme of work and requests } \\
\text { approval at an early date in order that } \\
\text { they can proceed with the continued } \\
\text { organisation of the work. They inform } \\
\text { that the works in respect of site } \\
\text { excavation and sub-soil drainage are } \\
\text { two weeks in advance of their } \\
\text { programme. The Architect is required } \\
\text { to respond to the contractor with } \\
\text { reference to the appropriate clause in } \\
\text { the contract. }\end{array}$ & 12 & $\begin{array}{l}\text { The contractor notifies that their Site } \\
\text { Agent, together with a representative of } \\
\text { the Roofing Sub-Contractor has now } \\
\text { inspected the area in question and } \\
\text { feels you are being most unreasonable } \\
\text { in respect of the bituminous felt roofing. } \\
\text { The Contractor indicates that there is a } \\
\text { slight unevenness in one small area } \\
\text { but, in general, the roofing work } \\
\text { throughout is up to their usual high } \\
\text { standard and complies in all respects } \\
\text { with their contractual obligations. The } \\
\text { Architect is required to respond to the } \\
\text { contractor with reference to the } \\
\text { appropriate clause in the contract. }\end{array}$ \\
\hline 5 & $\begin{array}{l}\text { The Clerk of Works advises that there } \\
\text { are two substantial existing trees on the } \\
\text { site which are not shown on contract } \\
\text { drawings. The Clerk of Works confirms } \\
\text { their understanding that the Contractor } \\
\text { has arranged for a sawmiller to cut } \\
\text { these down. The Architect is required } \\
\text { to respond to the contractor with } \\
\text { reference to the appropriate clause in } \\
\text { the contract. }\end{array}$ & 13 & $\begin{array}{l}\text { During a site inspection you note that a } \\
\text { joiner is fitting door ironmongery. The } \\
\text { lever handles being fitted look } \\
\text { unfamiliar and, on checking the } \\
\text { nominated suppliers tender, you find } \\
\text { that they are not the type specified and } \\
\text { you consider them to be inferior in both } \\
\text { design and quality. On enquiry, it is } \\
\text { discovered that about } 50 \% \text { of the doors } \\
\text { have already been fitted with the wrong } \\
\text { type. The Architect is required to } \\
\text { respond to the contractor with } \\
\text { reference to the appropriate clause in } \\
\text { the contract. }\end{array}$ \\
\hline 6 & $\begin{array}{l}\text { The Client notifies that they have paid } \\
\text { fees to account to date, based on } \\
\text { probable cost figures and now request } \\
\text { a detailed schedule of the present fee } \\
\text { position, plus a schedule of the fees, } \\
\text { expenses and VAT due to completion }\end{array}$ & 14 & $\begin{array}{l}\text { The Clerk of Works notifies that } \\
\text { Building Control visited the site. The } \\
\text { Clerk of Works further advises that the } \\
\text { half hour fire doors are not with } \\
\text { intumescent strips and that Building } \\
\text { Control requires these for Standards } \\
\text { compliance. In seeking clarification, the } \\
\text { contractor advises that the doors are } \\
\text { installed as Billed and Specified and } \\
\text { that there is no mention of these } \\
\text { intumescent strips. He insists on an A1 } \\
\text { if he is to supply and fit them. The } \\
\text { Architect is required to respond to the } \\
\text { contractor with reference to the } \\
\text { appropriate clause in the contract. }\end{array}$ \\
\hline
\end{tabular}


A. Agapiou, P. Maharg \& E. Nicol: Construction and Constructivism: Learning Contract Management and Administration via Simulated Transactions

\begin{tabular}{|c|c|c|c|}
\hline 7 & $\begin{array}{l}\text { The Architect reads in the newspaper } \\
\text { that the Union of Construction and } \\
\text { Allied Trades has announced that } \\
\text { negotiations with Employers' } \\
\text { representatives over the current pay } \\
\text { dispute had ended in deadlock. A } \\
\text { Union spokesperson stated that } \\
\text { industrial action was now inevitable and } \\
\text { that this would take the form of } \\
\text { withdrawal of labour in respect of } \\
\text { selected trades. He stated further that } \\
\text { all bricklayers would be on strike } \\
\text { shortly. }\end{array}$ & 15 & $\begin{array}{l}\text { The Contractor informs that they have } \\
\text { now completed the erection of the } \\
\text { above under the terms of the Contract } \\
\text { and propose that the date of this letter } \\
\text { will be the commencement of the } \\
\text { maintenance period. They request from } \\
\text { you Certificate of Practical Completion } \\
\text { releasing the retention monies. The } \\
\text { Architect is required to respond to the } \\
\text { contractor and prepare the appropriate } \\
\text { documentation accordingly. }\end{array}$ \\
\hline 8 & $\begin{array}{l}\text { The Quantity Surveyor advises that he } \\
\text { has noted, when measuring on site, } \\
\text { that the quality of the fireclay drain } \\
\text { pipes which have been used in the } \\
\text { works is not as high as the quality } \\
\text { described in the Bills of Quantities. The } \\
\text { Architect is required to respond to the } \\
\text { contractor with reference to the } \\
\text { appropriate clause in the contract. }\end{array}$ & 16 & $\begin{array}{l}\text { Subsequent to the receipt of the } \\
\text { Contractor's letter stating that he has } \\
\text { completed the building, the Architect } \\
\text { carries out an inspection and concludes } \\
\text { that the Contract Works have been } \\
\text { finished with the following exceptions: } \\
\text { - The fixing of a number of light- } \\
\text { fittings in the lavatories on the } \\
\text { third floor } \\
\text { - The completion of the kerbing } \\
\text { at one end of the car park } \\
\text { - The preparation and seeding of } \\
\text { an area of ground specified for } \\
\text { grass } \\
\text { - The erection of the flagpole on } \\
\text { the front of the building } \\
\text { The Architect is required to respond to } \\
\text { the contractor and prepare the } \\
\text { appropriate documentation accordingly. }\end{array}$ \\
\hline
\end{tabular}

In order to address each task, students were provided with access to all documentation within the SIMPLE platform they would require to solve a particular task through the use of electronic document libraries. These libraries contained all documentation relevant to the individual scenario and any standard forms participants need to submit in order to complete.

These included bespoke particulars of the JCT/SBCC 1998 building contract along with blank copies of Architects' Instruction and Completion Certificates created for the purposes of the simulation exercise. The actions taken by participants to solve an individual task were recorded in a Task Response Panel. This area allowed the students to record what actions, notes and communications they make in order to resolve a task. This allowed the class tutor to enter their particular response to actions, notes or queries. Once a task was completed successfully, the tutor released the next scenario and the participants were then invited to resolve the next transaction and so on until the simulation was successfully completed. 
A. Agapiou, P. Maharg \& E. Nicol: Construction and Constructivism: Learning Contract Management and Administration via Simulated Transactions

In the next section we shall discuss the evaluation of the project, and the results that we obtained from the evaluative process.

\section{Evaluation Process}

\section{Methodology}

A number of standard evaluation techniques were deployed during the course of the simulation incorporating analysis of questionnaire surveys and focus group discussions.

\section{Pre-course exercise}

Students were introduced to SIMPLE and the requirements for the assignment at a lecture. In the final few minutes of this lecture students were asked to express their thoughts and feelings about the exercise they were about to complete by answering the following questions in short written statements:

- What do you expect to be the main benefits of working in SIMPLE?

- What do you expect to be the main challenges or difficulties of working in SIMPLE?

- What prior experience or knowledge do you possess that might help you in your use of SIMPLE?

\section{Observations}

Halfway through the simulation the evaluator met two groups of students to observe their activities as they completed the assignment in their usual group meeting place, the computer laboratory of the Department of Architecture. Individual student interaction with the software as well as group negotiation activities were observed and at certain points during the observation students thought aloud as they worked, expressing their thoughts about using SIMPLE and about their experience of completing the assignment thus far.

\section{Post-course Questionnaire}

A small sample of students completed a questionnaire several weeks after the simulation had ended, following their receipt of grades for the assignment. The questionnaire consisted of both closed and open questions that were designed to elicit their thoughts and feelings about their experience of using SIMPLE and about completing the assignment generally. Questions were asked about timing, workload, resources, sense of engagement, ease of use and ease of collaboration.

\section{Focus Group}

The evaluator met a group of five students several weeks after the simulation. The session was recorded as an audio file and lasted approximately 45 minutes. Students 
A. Agapiou, P. Maharg \& E. Nicol: Construction and Constructivism: Learning Contract Management and Administration via Simulated Transactions

were invited to talk freely and anonymously about issues such as time, workload, appropriateness of training, technical problems, group issues and the appearance and ease of use of the SIMPLE platform. Students were also asked to list their key likes and dislikes related to their use of SIMPLE to complete the assignment.

\section{Tutor interview}

The evaluator interviewed the tutor for around one hour several weeks after the simulation had ended. The interview was recorded as an audio file and covered the tutor's experiences of using the SIMPLE tools to build a simulation, his experience of running the simulation, the successes and failures of delivering the assignment in this way and the lessons learned.

\section{Evaluation results}

Student general responses to the pre-course exercise are summarised in the following table (Table 2). The process of simulation always requires, to some degree what Coleridge (1817) defined as 'the willing suspension of disbelief'. When he coined the phrase Coleridge was referring to the quality of imagination to treat the representation of reality within an art work as being more than the mere artistic framing of events and emotions. The same applies to any form of simulation. Immersion in role is a key factor. Such immersion does not necessarily need to be the totality of what Csiksentmihalyi (1996) described as 'flow' - it can take place in textual worlds or docuverses, as Turkle (2005) described so well in her analyses of MUDs and MOOs. This is how SIMPLE has the potential to simulate professional practice - via the creation, by users themselves, of representations of their professional identities online within SIMPLE.

Table 2 Student responses to pre-course exercise

\section{Benefits of the simulation}

- Realism

- Learning about contracts

- Accessed anywhere any time

- Saves trees

- Better than lecture

- Central located info

- Quick response

- Easily accessed info

- Working directly with areas that are normally completed by a higher member of staff in the office

- Understand role of architect among a network of other professions in construction industry

- How to approach a problem

\section{Challenges in using the simulation}

- Relying on staff for swift feedback

- Group work (co-ordinating, finding time to meet)

- Lack of time/other commitments

- Learning how to use it

- Working in group round one computer

- Understanding language of clauses

- Unfamiliarity with situations and protocol 
A. Agapiou, P. Maharg \& E. Nicol: Construction and Constructivism: Learning Contract Management and Administration via Simulated Transactions

The SIMPLE scenario was extended into deeper role-play at certain points, when the tutor responded according to the character of the writer. What was interesting about this was that students did not seem to appreciate this role-play, though they do in other projects. For instance, a client wrote back to a firm of student architects either misreading their correspondence or irritated by wrong information sent by the students. In itself, this is legitimately part of the simulation: in real life, clients do get irritated if professionals make mistakes on their behalf. What matters is how the students recover from the situation, and what they learn from it. It needs to be made clear to students at the start of the simulation, and almost certainly in any feedback or debrief at the end, that such role-play is a valuable learning opportunity. However, as the students themselves commented, at such points of failure or conflict it is essential to be able to step out of role, and possibly consult with a mentor or other more senior figure as to the possible resolutions of the problem; and this is something that will be reviewed in future iterations of the project.

Much of the student feedback centred on the following issues:

\section{Timetabling}

Simulation can be a disruptive pedagogy in a number of ways, not least to timetabling of teaching and learning events. Students were aware that the project overlapped with studio time and commented on this in feedback. Actually, there is nothing wrong with this - studio time, after all, is yet another form of simulation. But because the DMP simulation was a stand-alone pilot project, it was viewed by students as an isolated experience. The DMP simulation could, however, be represented to students as necessary practice experience, and which must be timetabled by the students themselves so that they learn to manage both studio time and client/professional communications synchronously. This, after all, is what architects in practice are required to do. Students also commented that the simulation might have been better had it run intensively over several days. This is an interesting point, in that the experience would have been more immersive had it taken this shape and size. However it would have been less of a representation of what happens in a real architectural office. Perhaps the best approach would be to run a relatively simple and small-scale narrative over several days, give basic feedback on performance, and then run the larger and more complex narrative. Students themselves took a variety of approaches to the flexibility of the simulation.

One commented: 'I prefer to know in advance when deadlines will be and work mostly before the deadline'.

While another commented: 'You get what you're given and work around it!'

Another commented: 'We weren't told too much which was good so we could work things out for ourselves'. 


\section{A. Agapiou, P. Maharg \& E. Nicol: Construction and Constructivism: Learning Contract}

Management and Administration via Simulated Transactions

\section{Resources}

Resourcing within simulations requires different approaches than are normally taken in other teaching interventions. Students realised that independent learning was key to success in the simulation. As Maharg (2007) points out, the pacing of a simulation also affects the resources required: students need to be able to access resources quickly, in order to solve mini-problems that are part of a larger problem-set.

At the same time, if students are to seek the resources themselves, then this should be made clear as part of student expectation at the start of the simulation. Students commented that responses were slow; but in part this is borne of their expectations that online responses would be immediate.

Other students commented that a discussion forum would have been helpful as a learning resource. This is used in other SIMPLE simulations, and use of forums is a communications tool that is of benefit to simulation experience, not just within role but as a device where students can step out of role and obtain advice and information on a transaction.

\section{Simulation and work}

A number of students commented that they learned much from reading contractual documentation, working on document drafts and communicating these to clients and other professionals. They commented that they were made aware of poor working habits that they had picked up on placement as a result of performing in the simulation. There was some uncertainty about how to negotiate group work - some guidance on this will be given for the second year of the simulation. The relevance of the simulation to work experience was acknowledged by students:

'Very useful when working in an office, much more relevant than other classes'

\section{Feedback}

A feedback event was planned for the end of the simulation, but due to over-run it did not take place. Students commented that they would have welcomed this opportunity to receive feedback on performance. Feedback is actually given to students in role as they proceed through the simulation; but the lack of a senior architect figure for the firm or some mentor figure meant that opportunities for detailed feedback on drafts was lost. This will be reviewed for implementation in future years.

\section{Group work}

Some student groups performed well, but there were difficulties in other groups. As one student put it,

'Difficult working as a four. Split up work so certain members of the group worked in certain tasks, the rest on others. This meant didn't learn as much.' 


\section{A. Agapiou, P. Maharg \& E. Nicol: Construction and Constructivism: Learning Contract Management and Administration via Simulated Transactions}

In part there was a need to describe to students how such work might be undertaken in an office, and how the work might be performed within the simulation by the group. There was also the issue of extended group work within the simulation environment. Students need to be supported through this process, as they come to terms with their own strengths and weaknesses as co-workers.

The environment, with its deadlines and work patterns, can be a challenging one. As Barton \& Westwood (2006) point out, there are many learning issues that are raised by this approach. Probably the best way to deal with this is to discuss the topic with students at the start of the simulation, and give pointers as to best practice.

The critical issue is often that of collective responsibility within the group. If the group's individual members are assigned individual marks, then the emphasis is clearly on individual performance within the group, and students' work patterns will reflect this. However if the group is assessed as a collective, then work patterns to create collective work need to be developed by student groups. In other SIMPLE projects, particularly those run in the Glasgow Graduate School of Law, grades are assigned collectively to groups. This is made clear to the group at the start of the simulation, and models of working practices are suggested to students.

Above all, the firms must ensure that all documentation that is sent by the firm of student lawyers has been approved by all of them. They do not all necessarily need to lead in the drafting process, but collective agreement is essential for collective responsibility. In addition, the GGSL monitor groups through self- and peerassessment forms and regular workshops on group work process. The aim of this is to create both a learning community with the group and more generally a participatory culture within the programme of study. Simulation activities are uniquely adaptable to the development of these learning traits; but careful planning and leadership is required.

\section{Conclusion}

Professional degree courses such as Architecture incorporate a significant number of academic disciplines where the knowledge base of the tutor is often considered more significant than the reference material. It is within the professional degrees such as Architecture, that the limitations of the traditional approach have been recognised. In order to enable students to learn the professional discipline, alternative methods are required that can leverage knowledge from the tutor knowledge base and help students integrate that with more formal academic reference materials.

This article has described the use and efficacy of a transactional simulation environment to teach contract management and administration to postgraduate Architecture Students. 
A. Agapiou, P. Maharg \& E. Nicol: Construction and Constructivism: Learning Contract Management and Administration via Simulated Transactions

We have focused on the deployment of the SIMPLE platform in one class, and drawn conclusions from student responses to that implementation. The results of the evaluation have shown that the SIMPLE environment is a valuable method for the teaching of subject material where the knowledge base of the tutor is otherwise critical, and where a holistic approach to problem solving can be applied. However, while a transactional learning environment can be successfully implemented within an Architecture Practice module, there are a number of issues which require to be addressed by curriculum designers taking this educational approach. These primarily revolve around empowering the student toward self-learning and providing an environment in which they are invited to take responsibility for their own learning without suffering alienation.

Whilst it is accepted that one module in a course containing 10 discrete taught and studio modules may not be significant in the application of transactional-based learning, we consider that our approach has enabled the students to gain an insight into the complex inter-relationships within the degree programme (Barton and Maharg, 2006). The students agreed in evaluation that the transactional learning process is more like real situations and provides for deeper learning. This supports the claims made by Barton et al. (2006). The students found it an enjoyable experience. The timetabling presented some concerns in the planning of the module as noted by Maharg (2006). However, this became a management and logistical problem as the scenarios were released to the students. van Boxtel et al. (2000) and Barton and Westwood (2006) posit that group dynamics and communication are of paramount importance. Student evaluation data supported this - indeed group work was received positively by the majority, the students indicating not only that this was their preferred mode of method of working at university, but also in practice.

\section{All the resources for this simulation are available through simshare website http://www.simshare.org.uk/index.php}

\section{Acknowledgements}

An earlier version of this paper was presented at the $2^{\text {nd }}$ International Conference on Information Visualisation Conference as Agapiou, A, Maharg, P and Nicol, E. (2009) Learning contract management and administration using a simulated game environment, Information Visualisation Conference 09, 14-17 July 2009; Barcelona. ISBN 978-0-7695-3734-4/09. We are grateful to the publishers for permission to reproduce extracts of the material for re-publication. 
A. Agapiou, P. Maharg \& E. Nicol: Construction and Constructivism: Learning Contract Management and Administration via Simulated Transactions

\section{References}

Agapiou, A. (2006) The use and evaluation of a simulation game to teach professional practice skills to undergraduate architecture students. Journal of Education in the Built Environment, 1 (2), 3-14.

Barab, S. A., Squire, K. \& Dueber, B. (2000) A co-evolutionary model for supporting the emergence of authenticity. Educational Technology Research and Development, 48 (2), 37-62

Barton, K. \& Maharg, P. (2006) E-simulations in the wild: Interdisciplinary research, design and implementation. In: Aldrich, C., Gibson, D., Prensky, M. (Eds) Games and simulations in online learning: Research and development frameworks. Hershey PA: Information Science Publishing, pp. 115-148.

Barton, K., Maharg, P., Cunningham, C. D., \& Jones, G. T. (2006) Valuing what clients think: Standardized clients and the assessment of clinical competence. Clinical Law Review, 13 (1), 51-59.

Barton, K., McKellar, P. \& Maharg, P. (2007) Authentic fictions: Simulation, professionalism and legal learning. Clinical Law Review, 14 (1), 143-93.

Barton, K. \& Westwood, F. (2006) From student to trainee practitioner - a study of team working as a learning experience. Web Journal of Current Legal Issues, 3, http://webjcli.ncl.ac.uk/2006/issue3/barton-westwood3.html

Coleridge, S. T. (1817). Biographia Literaria. In: Jackson, H. J. (Ed.) (1985) Samuel Taylor Coleridge. Oxford: Oxford University Press, Ch 14, p.314.

Csiksentmihalyi, M. (1996) Creativity: Flow and the psychology of discovery and invention. New York: Harper Collins Publishers.

Deshpande, A. A. \& Huang, S. H. (2009) Simulation games in engineering education: A state-of-the-art review. Computer Applications in Engineering Education, 17 (1), 1-16.

Maharg, P. (2006) On the edge: ICT and the transformation of professional legal learning. Web Journal of Current Legal Issues, 3, http://webjcli.ncl.ac.uk/2006/issue3/maharg3.html.

Maharg, P. (2007) Transforming legal education: Learning and teaching the law in the early twenty-first century. London: Ashgate Publishing.

Maharg, P. \& Owen, M. (2007) Simulations, learning and the metaverse: Changing cultures in legal education. Journal of Information, Law \& Technology, 1, http://www2.warwick.ac.uk/fac/soc/law/elj/iilt/2007 1/maharg owen

O'Leary, T. (1997) On-line learning environments in architectural and construction education. Annual Conference of the Australasian Society for Computers in Learning in 
A. Agapiou, P. Maharg \& E. Nicol: Construction and Constructivism: Learning Contract Management and Administration via Simulated Transactions

Tertiary Education, Curtin University of Technology, Perth, Western Australia, December 7-10,

http://www.ascilite.org.au/conferences/perth97/papers/O'leary/O'leary.html

Turkle, S. (2005) The second self: Computers and the human spirit. 2nd revised ed. Cambridge MA: MIT Press.

van Boxtel, C., van der Linden, J. \& Kanselaar, G. (2000) Collaborative learning tasks and the elaboration of conceptual knowledge. Learning and Instruction, 10 (4), 331330. 